\title{
Effect of soil depth and increasing fertilization rate on yield and its components of two durum wheat varieties
}

\author{
Juan Hirzel ${ }^{1}$, and Iván Matus ${ }^{1^{*}}$
}

\begin{abstract}
Agronomic practices, climatic variables, and soil conditions are key factors in crop productivity. Although the effects of soil chemical properties and water and agronomic crop management are known, there is little information about effective soil depth and its influence on crop productivity. Since most crop fertilization systems are based on the productive potential associated with climatic conditions and chemical properties of the first $20 \mathrm{~cm}$ of soil depth, the objective of this study was to determine the importance of effective depth in terms of increasing fertilization rates on durum wheat (Triticum turgidum L. var. durum) productivity. Two experiments were conducted in the 2006-2007 season in the Santa Rosa Experimental Station (71 $54^{\prime}$ S , 36 31' W, 220 m a.s.1.) of the Instituto de Investigaciones Agropecuarias (INIA) located in south central Chile. We used the hard wheat cvs. Llareta-INIA and Corcolén-INIA because both respond differently to soil physicochemical properties. Each cultivar was sown in sectors with different depths: 1) $0.45 \mathrm{~m}$ depth, silt loam on river material and 2) 1.0 $\mathrm{m}$ depth, loam on deep sediments. Fertilization was: 1) control without fertilization, 2) basal fertilization (BF) based on P, $\mathrm{K}, \mathrm{Ca}, \mathrm{Mg}, \mathrm{S}, \mathrm{B}$, and $\mathrm{Zn}$ plus $90 \mathrm{~kg} \mathrm{~N}^{-1}$, and 3) BF plus $210 \mathrm{~kg} \mathrm{~N} \mathrm{ha}^{-1}$. Grain yield, plant height, and number of stems $\mathrm{m}^{-2}$ were positively affected by increasing depth of soil profile. The increasing fertilization rate affected grain yield and plant height. Grain yield for cv. Corcolén-INIA had a greater response than cv. Llareta-INIA when soil depth was increased.
\end{abstract}

Key words: Durum wheat, soil depth, fertilization, Triticum turgidum.

\section{INTRODUCTION}

Plant productivity is affected by climatic, soil, and agronomic factors. Climatic factors influence the likelihood of developing a particular species for productive purposes, while soil and agronomic factors determine the productivity level that will be achieved. Mengel and Kirkby (1987) indicate that texture and clay mineral type, structure, soil moisture, soil atmosphere, soil acidity or alkalinity $(\mathrm{pH})$, and salinity are among the important soil factors. Bengough et al. (2011) point out that root growth can be limited by physical, chemical, or biological factors and that the development of extensive root systems is very important in water- and nutrient-limited soil. Christopher et al. (2008) indicate that soil depth associated with soil capacity to retain moisture in the presence or absence of rainwater determines wheat (Triticum aestivum L.) productivity. For winter wheat, Zhang et al. (2004) show that $15 \%$ of the root mass at the maturity stage was located at a depth greater than $1 \mathrm{~m}$ within the soil profile, and that root density depth is directly associated with the capacity to use water stored in that zone. Heuvelmans

${ }^{1}$ Instituto de Investigaciones Agropecuarias INIA, Av. Vicente Méndez 515, Casilla 426, Chillán, Chile.

"Corresponding author (imatus@inia.cl).

Received: 28 March 2012.

Accepted: 15 November 2012.
(2010) states that soil water availability is a determining factor in agricultural production and is not only associated with climatic conditions, soil use, and soil properties, but also with the presence and fluctuations of groundwater during the growing season. Whitmore and Whalley (2009) indicate that root distribution at a greater depth contributes to improving yield in water stress conditions. Busscher et al. (2001) mention that corn (Zea mays L.) yield is limited by deep compacted strata because these reduce root exploration within the soil profile. Similarly, Whitmore et al. (2011) point out that wheat production is limited by soil mechanical resistance, a factor that is part of the root environment. Various studies of soil profile reserve indicate that determining nutrient availability in the superficial stratum $(0-20 \mathrm{~cm})$ is an inadequate indicator of the soil chemical properties or the effect of residual fertilization from the previous crop (Eghball et al., 2003; Hirzel et al., 2007; Li et al., 2011); this suggests the need to monitor these properties within the root-explorable soil profile. Richards (2008) specifies that the increase in depth explored by the roots and root density of cereals allows increased water and nutrient absorption from the soil, which increases productivity. McDonald (2006) demonstrates that subsoil physical properties are important in low rainfall areas and affect grain yield and water use efficiency in wheat and barley (Hordeum vulgare L.). In a wheat study, this same author determined that electrical conductivity (EC) parameters and nitrate concentrations 
in deep soil were significantly correlated with grain yield. Corre-Hellou et al. (2007) point out that there is a difference in nutrient extraction and aerial biomass production associated with the exploratory capacity of the root system of each species; this was evidenced by these authors in a study with pea (Pissum sativum L.) and barley where the difference was maximized and minimized with low and high $\mathrm{N}$ availability, respectively.

Soils in Chile vary in their physical properties within a same crop area, which is mainly associated with the depth of the arable soil profile; this affects the potential productivity of each crop within the same management system. In addition, distinct cultivars of a species respond differently to productive factors, thus affecting yield and yield components, which highlights plant height and the number of stems $\mathrm{m}^{-2}$ associated with biomass production. It is necessary to generate knowledge associated with soil physical properties and their relationship with productivity, but many producers do not clearly understand the importance of these soil physical properties with respect to chemical properties, and that some crop fertilization recommendation systems are based on the productive potential of a species only as a function of climatic conditions and chemical properties of the first $20 \mathrm{~cm}$ of soil depth. The objective of this study was to determine the effect of two effective depths of a volcanic ash soil and three fertilization rates on yield and some yield components in two varieties of durum wheat (T. turgidum L. var. durum).

\section{MATERIALS AND METHODS}

\section{Sites, soil, and treatments}

Two experiments were carried out in the 2006-2007 season in the Santa Rosa Experimental Station (71 ${ }^{\circ} 54^{\prime}$ S, $36^{\circ} 31^{\prime} \mathrm{W}, 220 \mathrm{~m}$ a.s.1.) of the Instituto de Investigaciones Agropecuarias (INIA) located in south central Chile. The climate is typical Mediterranean with a cold rainy winter and hot dry summer. The average annual rainfall of the site is $800 \mathrm{~mm}$, which is mainly concentrated between May and September. Hard wheat (T.turgidum var. durum) cvs. Llareta-INIA and Corcolén-INIA were used because both exhibit a different response to soil physicochemical properties. The silt loam volcanic ash soil is a Melanoxerands (CIREN, 1999). Soil samples at 0-20 cm depth were taken before sowing; soil chemical analysis was performed according to the methodology described by Sadzawka et al. (2006), who indicated limitations only for $\mathrm{Mg}, \mathrm{Zn}$, and B. In general, more shallow soil showed better chemical properties (Table 1). Crop rotation for both experiments was bean (Phaseolus vulgaris L.) - oat (Avena sativa L.) - wheat with no residue incorporation. Each cultivar was sown in sectors with different depths: 1) $0.45 \mathrm{~m}$ depth, silt loam on river material and 2) $1.00 \mathrm{~m}$ depth, loam on deep sediments. Soil depth was determined by locating soil pits on the edge of each experimental area
Table 1. Initial soil chemical properties of experimental sites (0-20 cm).

\begin{tabular}{|c|c|c|}
\hline \multirow[b]{2}{*}{ Property } & \multicolumn{2}{|c|}{ Soil } \\
\hline & Shallow $^{1}$ & Deep $^{2}$ \\
\hline $\mathrm{pH}$ & 6.23 & 6.27 \\
\hline Organic matter, $\%$ & 9.97 & 8.63 \\
\hline Inorganic $\mathrm{N}, \mathrm{mg} \mathrm{kg}^{-1}$ & 10.3 & 9.8 \\
\hline P-Olsen, $\mathrm{mg} \mathrm{kg}^{-1}$ & 22.6 & 18.0 \\
\hline Exchangeable $\mathrm{K}, \mathrm{cmol}_{(+)} \mathrm{kg}^{-1}$ & 179.0 & 99.0 \\
\hline Exchangeable Ca, $\mathrm{cmol}_{(+)} \mathrm{kg}^{-1}$ & 4.55 & 4.30 \\
\hline Exchangeable $\mathrm{Mg}, \mathrm{cmol}_{(+)} \mathrm{kg}^{-1}$ & 0.49 & 0.44 \\
\hline Exchangeable $\mathrm{Na}, \mathrm{cmol}_{(+)} \mathrm{kg}^{-1}$ & 0.16 & 0.17 \\
\hline Exchangeable $\mathrm{Al}, \mathrm{cmol}_{(+)} \mathrm{kg}^{-1}$ & 0.05 & 0.04 \\
\hline Available $\mathrm{S}, \mathrm{mg} \mathrm{kg}^{-1}$ & 10.1 & 10.1 \\
\hline Available Fe, mg kg & 28.0 & 25.4 \\
\hline Available $\mathrm{Mn}, \mathrm{mg} \mathrm{kg}$ & 2.47 & 1.89 \\
\hline Available $\mathrm{Zn}, \mathrm{mg} \mathrm{kg}$ & 0.32 & 0.24 \\
\hline Available $\mathrm{Cu}, \mathrm{mg} \mathrm{kg}$ & 1.09 & 1.07 \\
\hline Available B, mg kg & 0.41 & 0.38 \\
\hline
\end{tabular}

${ }^{1} 0.45 \mathrm{~m}$ depth; ${ }^{2} 1.00 \mathrm{~m}$ depth.

and calculated with a RedLine Professional measuring tape.

Experiments included the following fertilization treatments: 1) control without fertilization; 2) $120 \mathrm{~kg}$ $\mathrm{P}_{2} \mathrm{O}_{5}$ (triple superphosphate), $98 \mathrm{~kg} \mathrm{~K}_{2} \mathrm{O}$ (potassium, magnesium chloride, and potassium sulfate), $52 \mathrm{~kg} \mathrm{CaO}$ (triple superphosphate), $36 \mathrm{~kg} \mathrm{MgO}$ (potassium and magnesium sulfate), $44 \mathrm{~kg} \mathrm{~S}$ (potassium and magnesium sulfate), $1 \mathrm{~kg}$ B (borax), and $1 \mathrm{~kg} \mathrm{Zn} \mathrm{(zinc} \mathrm{sulfate)} \mathrm{ha-1;}$ this mixture, called base fertilization (BF), plus $90 \mathrm{~kg} \mathrm{~N}$ (urea) ha-1 applied three times (33\% at sowing, 33\% at tillering, and $33 \%$ at stem elongation); and 3) $\mathrm{BF}+210 \mathrm{~kg}$ $\mathrm{N}$ (urea) ha ${ }^{-1}$ applied three times (33\% at sowing, 33\% at tillering, and $33 \%$ at stem elongation or Z0, Z23, and Z31 on the Zadoks scale, respectively) (Zadoks et al., 1974). The $\mathrm{N}$ rates were determined in the ranges of $\mathrm{N}$ response in the different soil depths in this experiment. The other nutrient rates were determined by soil chemical analysis.

\section{Crop management and evaluated parameters}

Each experimental unit consisted of six 2-m long rows spaced $0.2 \mathrm{~m}$ between rows. The cultivars were sown on 15 August 2006 with a $220 \mathrm{~kg} \mathrm{ha}^{-1}$ sowing density. The seed bed was prepared by plowing at a $30 \mathrm{~cm}$ depth followed by a superficial preparation with a vibro-cultivator (Gravely Professional, USA). The fertilization base was applied before sowing and irrigation was applied at the heading, milk, and dough grain stages as a complement to accumulated rainfall between July and December $(650 \mathrm{~mm})$. Irrigation $(50 \mathrm{~mm})$ each time was sufficient to maintain adequate soil moisture for crop development. An iodosulfuron-methyl-sodium herbicide was applied at a rate of $300 \mathrm{~g} \mathrm{ha}^{-1}$ at the tillering stage to control grasses and dicotyledons. Foliar fungicides or insecticides were unnecessary because diseases and insects did not appear. Hard wheat plants were harvested at the hard kernel stage on 7 January 2007 and grain yield $\left(\mathrm{Mg} \mathrm{ha}^{-1}\right)$, hectoliter weight $\left(\mathrm{kg} \mathrm{hL}^{-1}\right)$, plant height $(\mathrm{cm})$, and number of stems 
$\mathrm{m}^{-2}$ were evaluated. Yield was determined from a sample of four 2-m long rows from each plot. Hectoliter weight of this harvested grain sample was determined with the L. Schopper scale $(0.25 \mathrm{~L})$ and the result expressed as $\mathrm{kg} \mathrm{hL}^{-1}$. Plant height was measured from the soil surface to the top of the spikes without considering awns; the number of tillers per $\mathrm{m}^{-2}$ was counted as the number of tillers per linear meter.

\section{Experimental design}

The experimental design was a randomized complete block in a split-plot arrangement with four replicates where soil depths were treatments corresponding to main plots and sub-treatments were fertilization levels corresponding to sub-plots. Results were analyzed with ANOVA and Tukey's test $(\mathrm{P}=0.05)$ by the SAS general model procedure (SAS Institute, 1989). The effects of each soil depth on yield were compared by orthogonal contrasts when there was interaction among sources of variation.

\section{RESULTS AND DISCUSSION}

Grain yield, plant height, and number of stems $\mathrm{m}^{-2}$ were affected by soil depth in both cultivars $(\mathrm{P}<0.05)$ (Table 2). Hectoliter weight (HW) was only influenced by soil depth in 'Llareta-INIA' $(\mathrm{P}<0.05)$ (Table 2). Fertilization treatments had an effect on grain yield and plant height $(\mathrm{P}<$ 0.05 ) (Table 2). The number of stems $\mathrm{m}^{-2}$ was only affected by fertilization treatment in 'Corcolén-INIA' (Table 2). Hectoliter weight was not influenced by fertilization treatments in either of the evaluated cultivars $(\mathrm{P}>0.05)$ (Table 2). In addition, soil depth and fertilization treatments did not interact with evaluated parameters for 'CorcolénINIA' (Table 2) whereas grain yield interacted with soil depth and fertilization for 'Llareta-INIA' (Table 2).

Figures $1 \mathrm{a}$ and $1 \mathrm{~b}$ show that grain yield in both cultivars was positively affected by soil depth for 'Corcolén-INIA' and 'Llareta-INIA', respectively. This beneficial effect is due to several factors including the higher volume explored by the roots (Zhang et al., 2004) and the higher soil volume with no mechanical restrictions (Whitmore et al., 2011). The increase in the fertilization rate also had an effect on grain yield; there were differences in
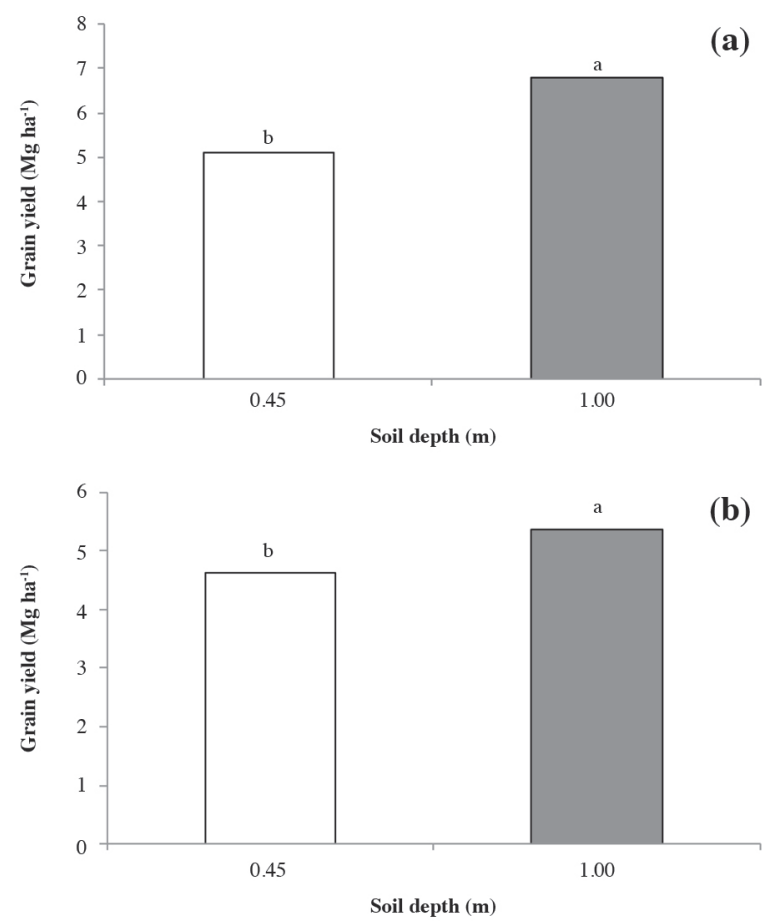

Different letters for each bar indicate significant differences among treatments according to Tukey's test $(\mathrm{P}<0.05)$.

Means group different fertilization levels used for each treatment.

Contrasts were generated with the following treatments: $+\mathrm{C} 0.45 \mathrm{~m}+$ (base fertilization $[\mathrm{BF}]+90 \mathrm{~N} 0.45 \mathrm{~m})+(\mathrm{BF}+210 \mathrm{~N} 0.45 \mathrm{~m})-\mathrm{C} 1.0 \mathrm{~m}-$ $(\mathrm{BF}+90 \mathrm{~N} 1.0 \mathrm{~m})-(\mathrm{BF}+210 \mathrm{~N} 1.0 \mathrm{~m})$.

Figure 1. Grain yield for two soil depths of (a) cv. Corcolén-INIA, and (b) cv. Llareta-INIA.

production associated with effective soil depth (Figures $2 \mathrm{a}$ and $2 \mathrm{~b}$ ) when taking into consideration the greater root exploratory capacity and its relationship with the recovery of applied nutrients (Richards, 2008). Grain yields for fertilization treatments fluctuated between 6.3 and 7.7 $\mathrm{Mg} \mathrm{ha}^{-1}$ for 'Corcolén-INIA' and between 5.5 and 6.6 for 'Llareta-INIA' (Figures 2a and 2b, respectively); these were higher than the values reported by May et al. (2008) for hard wheat fertilized with lower or similar $\mathrm{N}$ rates $\left(41.5,85.0\right.$, and $\left.140.0 \mathrm{~kg} \mathrm{~N} \mathrm{ha}^{-1}\right)$ and slightly lower than those indicated by some authors for bread wheat in similar soils and climatic conditions (Mellado, 2000; Campillo

Table 2. Significance levels for grain yield, hectoliter weight, plant height, and number of stems $\mathbf{m}^{-2}$ of cv. Corcolén-INIA and cv. Llareta-INIA for two effective soil depths and three fertilization treatments.

\begin{tabular}{|c|c|c|c|c|c|c|}
\hline \multirow[b]{2}{*}{ Characteristic } & \multicolumn{6}{|c|}{ Source of variation } \\
\hline & $\begin{array}{l}\text { Soil depth } \\
\text { (S) }\end{array}$ & $\begin{array}{l}\text { Fertilization } \\
\text { (F) }\end{array}$ & $\begin{array}{l}\text { Interaction } \\
(\mathrm{S} * \mathrm{~F})\end{array}$ & $\begin{array}{l}\text { Soil depth } \\
\text { (S) }\end{array}$ & $\begin{array}{l}\text { Fertilization } \\
\text { (F) }\end{array}$ & $\begin{array}{c}\text { Interaction } \\
(\mathrm{S} * \mathrm{~F})\end{array}$ \\
\hline & $\longrightarrow$ & Corcolén-INI & - & 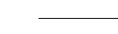 & Llareta-INIA & - \\
\hline Grain yield, $\mathrm{Mg} \mathrm{ha}^{-1}$ & $* *$ & $* *$ & ns & $* *$ & $* *$ & $*$ \\
\hline Hectoliter weight, $\mathrm{kg} \mathrm{hL}^{-1}$ & ns & ns & ns & $* *$ & ns & ns \\
\hline Plant height, $\mathrm{cm}$ & $* *$ & $* *$ & ns & $* *$ & $* *$ & ns \\
\hline Number of stems $\mathrm{m}^{-2}$ & $* *$ & $*$ & ns & $*$ & ns & ns \\
\hline
\end{tabular}

${ }^{*} \mathrm{P}<0.01 ;{ }^{* *} 0.01<\mathrm{P}<0.05 ;$ ns: non significant $(\mathrm{P}>0.05)$

Soil had (1) $0.45 \mathrm{~m}$ depth and (2) $1.00 \mathrm{~m}$ depth.

Treatments were (1) control without fertilization, (2) base fertilization (BF: $120 \mathrm{~kg} \mathrm{P}_{2} \mathrm{O}_{5}, 98 \mathrm{~kg} \mathrm{~K} \mathrm{O}_{2}, 52 \mathrm{~kg} \mathrm{CaO}, 36 \mathrm{~kg} \mathrm{MgO}, 44 \mathrm{~kg} \mathrm{~S}, 1 \mathrm{~kg} \mathrm{~B}$, and $1 \mathrm{~kg} \mathrm{Zn} \mathrm{ha-1)} \mathrm{+}$ $90 \mathrm{~kg} \mathrm{~N} \mathrm{ha}^{-1}$, and (3) BF $+210 \mathrm{~kg} \mathrm{~N} \mathrm{ha}^{-1}$. 

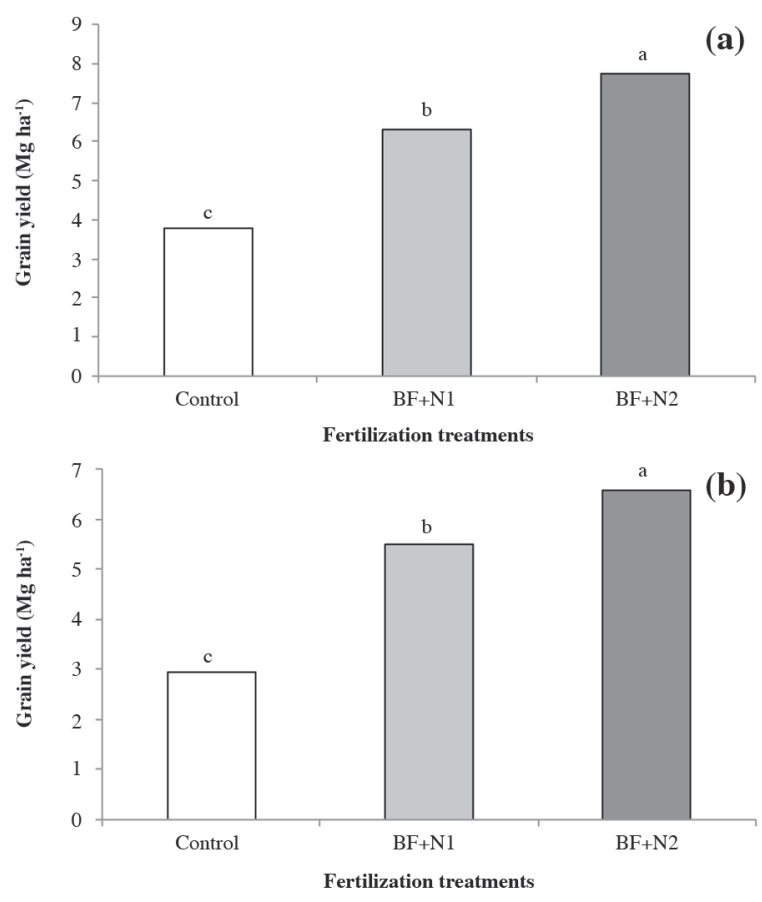

Different letters for each column indicate significant differences among treatments according to Tukey's test $(\mathrm{P}<0.05)$.

Fertilization treatments: Control without fertilization; basal fertilization (BF): $120 \mathrm{~kg} \mathrm{P}_{2} \mathrm{O}_{5}, 98 \mathrm{~kg} \mathrm{~K} 2 \mathrm{O}, 52 \mathrm{~kg} \mathrm{CaO}, 36 \mathrm{~kg} \mathrm{MgO}, 44 \mathrm{~kg} \mathrm{~S}, 1 \mathrm{~kg} \mathrm{~B}$, and $1 \mathrm{~kg} \mathrm{Zn} \mathrm{ha}{ }^{-1}$ at planting; $\mathrm{N} 1: 90 \mathrm{~kg} \mathrm{~N} \mathrm{ha}^{-1}$ in three splits (33\% Z0, $33 \% \mathrm{Z} 23$, and $33 \% \mathrm{Z} 31$ ); and $\mathrm{N} 2: 210 \mathrm{~kg} \mathrm{~N}^{-1}$ in three splits (33\% Z0, $33 \% \mathrm{Z} 23$, and $33 \% \mathrm{Z} 31$ ).

Means group different evaluated effective soil depths for each treatment

Figure 2. Effect of three fertilization treatments on grain yield, (a) cv. Corcolén-INIA and (b) cv. Llareta-INIA.

et al., 2007). This positive effect on yield for fertilization treatments is the result of applying a higher $\mathrm{N}$ rate; this coincides with results found by Campillo et al. (2007) for bread wheat and May et al. (2008) for durum wheat. On the average, 'Corcolén-INIA' in shallow soil achieved $73 \%$ of the grain yield obtained in deep soil (Figure 1a) whereas 'Llareta-INIA' achieved $86 \%$ of the yield in deep soil (Figure 1b). This indicates that this cultivar has better adaptability in soils with lower productive potential associated with their physical properties. In the absence of fertilization, 'Corcolén-INIA' had a relative yield of $65 \%$ in soil with physical limitations as compared to soil with no limitations whereas relative yield was $75 \%$ for the intermediate level of fertilization (Table 3). On the other hand, relative yield of 'Corcolén-INIA' was $80 \%$ with a high soil fertilization level with physical limitations as compared with soil with no limitations (Table 4). The relative differences in yield for 'Llareta-INIA' in soil with physical limitations and no limitations was $88 \%, 88 \%$, and $86 \%$ for conditions without fertilization, intermediate fertilization, and high fertilization, respectively (Table 3). These results suggest that 'Corcolén-INIA' has a higher response to fertilization in soil with physical
Table 3. Grain yield ( $\left.\mathrm{Mg} \mathrm{ha}^{-1}\right)$ of two durum wheat cultivars for two effective soil depths and three fertilization treatments.

\begin{tabular}{lcccccc}
\hline & \multicolumn{2}{c}{ Corcolén-INIA } & & \multicolumn{2}{c}{ Llareta-INIA } \\
\cline { 2 - 3 } \cline { 5 - 6 } & Shallow soil & Deep soil & & Shallow soil & Deep soil \\
\hline Control & $2.99 \mathrm{cB}$ & $4.60 \mathrm{cA}$ & & $2.76 \mathrm{aB}$ & $3.14 \mathrm{cA}$ \\
$\mathrm{BF}+90 \mathrm{~kg} \mathrm{~N}$ & $5.42 \mathrm{bB}$ & $7.22 \mathrm{bA}$ & & $5.07 \mathrm{bB}$ & $5.90 \mathrm{bA}$ \\
$\mathrm{BF}+210 \mathrm{~kg} \mathrm{~N}$ & $6.88 \mathrm{aB}$ & $8.61 \mathrm{aA}$ & & $6.08 \mathrm{aB}$ & $7.10 \mathrm{aA}$ \\
\hline
\end{tabular}

Different uppercase letters in columns for a given cultivar indicate significant difference according to Tukey's test $(\mathrm{P}<0.05)$.

Different lowercase letters in rows for a given cultivar and same soil type indicate significant differences according to Tukey's test $(\mathrm{P}<0.05)$.

Shallow soil: $0.45 \mathrm{~m}$ effective depth; Deep soil: $1.00 \mathrm{~m}$ effective depth.

Fertilization treatments: Control without fertilization; base fertilization (BF: $120 \mathrm{~kg}$ $\mathrm{P}_{2} \mathrm{O}_{5}, 98 \mathrm{~kg} \mathrm{~K}_{2} \mathrm{O}, 52 \mathrm{~kg} \mathrm{CaO}, 36 \mathrm{~kg} \mathrm{MgO}, 44 \mathrm{~kg} \mathrm{~S}, 1 \mathrm{~kg} \mathrm{~B}$, and $\left.1 \mathrm{~kg} \mathrm{Zn} \mathrm{ha}{ }^{-1}\right)+90$ $\mathrm{kg} \mathrm{Nha}^{-1}$; and $\mathrm{BF}+210 \mathrm{~kg} \mathrm{~N} \mathrm{ha}^{-1}$.

limitations and 'Llareta-INIA' adapts better to soil with physical limitations. Yield of 'Corcolén-INIA' under adequate physical property conditions and fertilization management was similar to that reported by Hirzel et al. (2010) for a volcanic soil with no physical restrictions; yield of 'Llareta-INIA' in this study was lower than results pointed out by these authors. This can be due to climatic differences registered for each study (data not evaluated) since both are spring habit cultivars, and it is reported that rainfall and air temperature during the growth period affect both grain yield and yield components of durum wheat (May et al., 2008). Mengel and Kirkby (1987) indicate that rainfall has an effect on moisture level and soil atmosphere with consequences on yield for the generality of plants.

For HW parameter, plant height, and number of stems per $\mathrm{m}^{2}$, an increase in soil depth and fertilization rate for 'Corcolén-INIA' positively affected plant height and number of stems $\mathrm{m}^{-2}$ (Table 4); both parameters are directly associated with biomass production. These two sources of variation in 'Llareta-INIA' only positively influenced plant height (Table 5). On the other hand, HW was unaffected by the evaluated treatments, because it is a characteristic with limited variability between cultivars (Matus, 2007). In general, the plant height and number of stems $\mathrm{m}^{-2}$ variables were higher in 'Corcolén-INIA' than in 'Llareta-INIA' (Tables 4 and 5 , respectively) and affect the higher yield obtained in this cultivar.

\section{CONCLUSIONS}

An increase in the soil depth profile positively affected grain yield, plant height, and number of stems $\mathrm{m}^{-2}$ in durum wheat. Grain yield increased $37 \%$ and $16 \%$ for 'Corcolén-INIA' and 'Llareta-INIA', respectively, in deep soil as compared with shallow soil. The fertilization rate influenced grain yield and plant height. Grain yield increased 22\% and 20\% for 'Corcolén-INIA' and 'LlaretaINIA', respectively, with the higher $\mathrm{N}$ rate as compared with no $\mathrm{N}$ fertilization. Grain yield of cv. Corcolén-INIA exhibited a greater response than cv. Llareta-INIA when 
Table 4. Comparison of means for productive parameters and quality of durum wheat cv. Corcolén-INIA for two effective soil depths and three fertilization treatments.

\begin{tabular}{|c|c|c|c|c|c|}
\hline \multirow[b]{2}{*}{ Characteristic } & \multicolumn{2}{|c|}{ Soil depth (m) } & \multicolumn{3}{|c|}{ Fertilization } \\
\hline & 0.45 & 1.00 & Control & $\mathrm{BF}+90 \mathrm{~kg} \mathrm{~N} \mathrm{ha}^{-1}$ & $\mathrm{BF}+210 \mathrm{~kg} \mathrm{~N} \mathrm{ha}^{-1}$ \\
\hline Hectoliter weight, $\mathrm{kg} \mathrm{hL}^{-1}$ & $85.0 \mathrm{a}$ & $85.0 \mathrm{a}$ & $84.5 \mathrm{a}$ & $85.4 \mathrm{a}$ & $85.1 \mathrm{a}$ \\
\hline Plant height, $\mathrm{cm}$ & $78.2 b$ & $81.4 \mathrm{a}$ & $70.4 \mathrm{c}$ & $82.3 b$ & $86.8 \mathrm{a}$ \\
\hline Number of stems $\mathrm{m}^{-2}$ & $461.0 \mathrm{~b}$ & $759.0 \mathrm{a}$ & $522.0 \mathrm{~b}$ & $611.0 \mathrm{ab}$ & $696.0 \mathrm{a}$ \\
\hline
\end{tabular}

Different letters among means for soil types or fertilization treatments indicate significant differences according to Tukey's test $(\mathrm{P}<0.05)$.

Fertilization treatments: Control without fertilization; base fertilization (BF: $120 \mathrm{~kg} \mathrm{P}_{2} \mathrm{O}_{5}, 98 \mathrm{~kg} \mathrm{~K} \mathrm{O}_{2}, 52 \mathrm{~kg} \mathrm{CaO}, 36 \mathrm{~kg} \mathrm{MgO}, 44 \mathrm{~kg} \mathrm{~S}, 1 \mathrm{~kg} \mathrm{~B}$, and $1 \mathrm{~kg} \mathrm{Zn}$ ha ${ }^{-1}$ ) $+90 \mathrm{~kg} \mathrm{~N} \mathrm{ha}^{-1}$; and $\mathrm{BF}+210 \mathrm{~kg} \mathrm{~N} \mathrm{ha}^{-1}$.

Table 5. Comparison of means for productive parameters and quality of durum wheat cv. Llareta-INIA for two effective soil depths and three fertilization treatments.

\begin{tabular}{|c|c|c|c|c|c|}
\hline \multirow[b]{2}{*}{ Characteristic } & \multicolumn{2}{|c|}{ Soil depth $(\mathrm{m})$} & \multicolumn{3}{|c|}{ Fertilization } \\
\hline & 0.45 & 1.00 & Control & $\mathrm{BF}+90 \mathrm{~kg} \mathrm{~N} \mathrm{ha}{ }^{-1}$ & $\mathrm{BF}+210 \mathrm{~kg} \mathrm{~N} \mathrm{ha}^{-1}$ \\
\hline Hectoliter weight, $\mathrm{kg} \mathrm{hL}^{-1}$ & $85.1 \mathrm{a}$ & $85.9 \mathrm{a}$ & $85.4 \mathrm{a}$ & $85.6 \mathrm{a}$ & $85.5 \mathrm{a}$ \\
\hline Plant height, $\mathrm{cm}$ & $73.2 \mathrm{~b}$ & $77.6 \mathrm{a}$ & $65.0 \mathrm{c}$ & $78.9 \mathrm{~b}$ & $82.3 \mathrm{a}$ \\
\hline Number of stems $\mathrm{m}^{-2}$ & $480.0 \mathrm{a}$ & $560.0 \mathrm{a}$ & $486.0 \mathrm{a}$ & $506.0 \mathrm{a}$ & $558.0 \mathrm{a}$ \\
\hline
\end{tabular}

Different letters among means for soil types or fertilization treatments indicate significant differences according to Tukey's test $(\mathrm{P}<0.05)$.

Fertilization treatments: Control without fertilization; base fertilization (BF: $120 \mathrm{~kg} \mathrm{P}_{2} \mathrm{O}_{5}, 98 \mathrm{~kg} \mathrm{~K} \mathrm{O}, 52 \mathrm{~kg} \mathrm{CaO}, 36 \mathrm{~kg} \mathrm{MgO}, 44 \mathrm{~kg} \mathrm{~S}, 1 \mathrm{~kg} \mathrm{~B}$, and $1 \mathrm{~kg} \mathrm{Zn} \mathrm{ha-1)}$ $+90 \mathrm{~kg} \mathrm{~N} \mathrm{ha}^{-1}$; and $\mathrm{BF}+210 \mathrm{~kg} \mathrm{~N}^{-1}$

soil depth was increased. Soil depth must be considered when determining the potential yield of durum wheat.

\section{LITERATURE CITED}

Bengough, A.G., B.M. McKenzie, P.D. Hallett, and T.A. Valentine. 2011. Root elongation, water stress, and mechanical impedance: a review of limiting stresses and beneficial root tip traits. Journal of Experimental Botany 62:59-68.

Busscher, W.J., J.R. Frederick, and P.J. Bauer. 2001. Effect of penetration resistance and timing of rain on grain yield of narrowrow corn in a coastal plain loamy sand. Soil \& Tillage Research 63:15-24.

Campillo, R., C. Jobet, y P. Undurraga. 2007. Optimización de la fertilización nitrogenada para trigo de alto potencial de rendimiento en Andisoles de la Región de La Araucanía, Chile. Agricultura Técnica 67:281-291.

Christopher, J.T., A.M. Manschadi, G.L. Hammer, and A.K. Borrell. 2008. Developmental and physiological traits associated with high yield and stay-green phenotype in wheat. Australian Journal of Agricultural Research 59:354-364.

CIREN. 1999. Descripciones de suelos materiales y símbolos: Estudio Agrológico VIII Región. Publicación CIREN Nº121.583 p. Centro de Estudios de Recursos Naturales (CIREN), Santiago, Chile.

Corre-Hellou, G., N. Brisson, M. Launay, J. Fustec, and Y. Crozat. 2007. Effect of root depth penetration on soil nitrogen competitive interactions and dry matter production in pea-barley intercrops given different soil nitrogen supplies. Field Crops Research 103:76-85.

Eghball, B., J. Schepers, M. Negahban, and M. Schlemmer. 2003. Spatial and temporal variability of soil nitrate and corn yield: Multifractal analysis. Agronomy Journal 95:339-346.

Heuvelmans, G. 2010. Development and credibility assessment of a metamodel relating water table depth to agricultural production. Agricultural Water Management 97:1731-1741.

Hirzel, J., I. Matus, and R. Madariaga. 2010. Effect of split nitrogen applications on durum wheat cultivars in volcanic soil. Chilean Journal of Agricultural Research 70:590-595.

Hirzel, J., I. Walter, P. Undurraga, and M. Cartagena. 2007. Residual effects of poultry litter on silage maize (Zea mays L.) growth and soil properties derived from volcanic ash. Spanish Journal of Agricultural Research 53:480-488.
Li, C-J., Y.Y. Li, C-B. Yu, J-H. Sun, P. Christie, M. An, et al. 2011. Crop nitrogen use and soil mineral nitrogen accumulation under different crops combinations and patterns of strip intercropping in northwest China. Plant and Soil 342:221-231.

Matus, I. 2007. Mejoramiento genético para rendimiento y calidad de trigo candeal en Chile. In Acevedo, E., y P. Silva (eds.) Trigo candeal. Calidad, mercado y zonas de cultivo. Serie Ciencias Agronómicas N¹2. p. 119-128. Universidad de Chile, Santiago, Chile.

May, W.E., M.R. Fernández, C.B. Holzapfel, and G.P. Lafond. 2008. Influence of phosphorous, nitrogen, and potassium chloride placement and rate on durum wheat yield and quality. Agronomy Journal 100:1173-1179.

McDonald, C.K. 2006. Effect of soil properties on variation in growth, grain yield and nutrient concentration of wheat and barley. Australian Journal of Experimental Agriculture 46:93-105.

Mellado, M. 2000. Genetic improvement in bread wheats (Triticum aestivum L.) in the South Central area of Chile: Analysis of grain yield and related variables in spring varieties. Chilean Journal of Agricultural Research 60:32-42.

Mengel, K., and E. Kirkby. 1987. Principles of plant nutrition. $4^{\text {th }}$ ed. 687 p. Internal Potash Institute, Worblaufen-Bern, Switzerland.

Richards, R. 2008. Genetic opportunities to improve cereal root systems for dryland agriculture. Plant Production Science 11:1216.

Sadzawka, A., M.A. Carrasco, R. Grez, M. Mora, H. Flores, y A. Neaman. 2006. Métodos de análisis recomendados para los suelos de Chile. 164 p. Serie Actas INIA N ${ }^{\circ} 34$. Instituto de Investigaciones Agropecuarias INIA, Santiago, Chile.

SAS Institute. 1989. Usage and reference. Version 6. 501 p. SAS Institute, Cary, North Carolina, USA.

Whitmore, A.P., and W.R. Whalley. 2009. Physical effects of soil drying on roots and crop growth. Journal of Experimental Botany 60:2845-2857.

Whitmore, A.P., W.R. Whalley, N.R. Bird, C.W. Watts, and A.S. Gregory. 2011. Estimating soil strength in the rooting zone of wheat. Plant and Soil 339:363-375.

Zadoks, J.C., T.T. Chang, and C.F. Konzak. 1974. A decimal code for the growth stages of cereals. Weed Research 14:415-421.

Zhang, X., D. Pei, and S. Chen. 2004. Root growth and soil water utilization of winter wheat in the North China Plain. Hydrological Processes 18:2275-2287. 